\title{
Nutritional requirements of digestible threonine for growing meat-type quails
}

\author{
Ana Paula Silva Ton ${ }^{1}$, Antonio Claudio Furlan², Elias Nunes Martins², Eliany Batista ${ }^{1}$, \\ Tiago Junior Pasquetti ${ }^{1}$, Carina Scherer ${ }^{1}$, Alexandre Shigueki Iwahashi ${ }^{1}$, Thays Cristina \\ Oliveira de Quadros ${ }^{3}$
}

\footnotetext{
${ }^{1}$ Programa de Pós-Graduação em Zootecnia, Universidade Estadual de Maringá.

${ }^{2}$ Departamento de Zootecnia, Universidade Estadual de Maringá.

${ }^{3}$ Universidade Estadual de Maringá.
}

\begin{abstract}
The objective of this study was to estimate the nutrient requirements of digestible threonine for meat-type quails (Coturnix coturnix sp) in the growth phase. A total of 1350 not sexed meat-type quails were distributed in a completely randomized design with six threonine levels $(10.80,11.50,12.20,12.90,13.60$ and $14.30 \mathrm{~g} / \mathrm{kg}$ as fed), five replications and 45 quails per experimental unit, from 1 to 14 days of age. The threonine levels in the diet had a quadratic effect on body weight, feed intake and weight gain. Estimates for highest body weight $(79.41 \mathrm{~g})$, feed intake $(128.96 \mathrm{~g} / \mathrm{bird})$ and weight gain $(70.73 \mathrm{~g})$ were observed with diets containing $12.60 \mathrm{~g} / \mathrm{kg}$ of digestible threonine. According to the LRP model, the threonine intake was estimated at $13.40 \mathrm{~g} / \mathrm{kg}$ of digestible threonine. Protein deposition rate and energy retained in the carcass showed quadratic effect, with estimated digestible threonine levels of 11.80 and $12.00 \mathrm{~g} / \mathrm{kg}$ in the diet for maximum protein deposition rate $(2.00 \mathrm{~g} / \mathrm{bird})$ and retained energy in the carcass $(15.88 \mathrm{kcal} / \mathrm{g})$, respectively. There was a linear effect on feed cost per $\mathrm{kg}$ of live weight gain as threonine levels were increased. Nutritional requirement of digestible threonine for meat-type quails for maximum growth is $12.60 \mathrm{~g} / \mathrm{kg}$, corresponding to a digestible threonine:digestible lysine ratio of 67.02 .
\end{abstract}

Key Words: carcass composition, performance, synthetic amino acids

\section{Introduction}

The constant population growth has encouraged the use of other birds as new options for protein sources. The demand for meat quality of a demanding consumer market justifies the significant increment in meat quail production (Winter et al., 2006).

Concerned about the demand of consumer market, Perdigao $^{\circledR}$, a local poultry company, has introduced a new quail strain for meat production in Brazil which was gradually called Italian lineage by producers. In this context, researchers are looking for better knowledge of available strains in order to establish performance indexes, contributing to the full development of the meat-type quail chain (Móri et al., 2005).

Recent advances in knowledge of protein metabolism and the emergence of new synthetic amino acids of largescale production and lower prices have allowed nutritionists to formulate diets closer to the requirement of animals, improving the utilization of dietary protein, reducing costs and harmful waste to the environment. Another advantage of synthetic amino acid use is the possibility to establish an ideal ratio between all amino acids in the diet: the ideal protein concept, which contributes to reduce protein levels in the diet (Brumano, 2009).
In poultry diets based on corn and soybean meal, threonine is the third limiting amino acid, preceded by the sulfur amino acids and lysine. It is required for the protein synthesis and maintenance of body protein turnover, and acts on collagen and elastin synthesis and production of antibodies (Lelis \& Calderano, 2011). The pure L-threonine is totally digestible and is commercially available, offering flexibility in diet formulation. Its supplementation allows for inclusion of lowerprotein feeds, preventing nitrogen excretion and thereby environmental pollution (Umigi et al., 2007).

The lack of information about threonine requirements for meat-type quails during growth guided this study, which was conducted in order to better estimate digestible threonine levels for maximum performance, chemical carcass composition, protein and fat deposition on carcass, retained energy in the carcass and the feed cost per kilogram of live weight gained for meat-type quails (Coturnix coturnix $s p$ ) in the growth phase.

\section{Material and Methods}

The experiment was conducted at Setor de Coturnicultura on Iguatemi Experimental Farm, Universidade Estadual de Maringá - UEM. 
A total of 1350 one-day-old not sexed meat-type quails (Coturnix coturnix $s p$ ), with average initial body weight of $8.68 \pm 0.066 \mathrm{~g}$ were distributed in a completely randomized design with six levels of digestible threonine, five replicates and 45 birds per experimental unit.

The birds were housed in a conventional shed, covered with and asbestos fiber roof, divided into 30 pens of $2.5 \mathrm{~m}^{2}$ with a dirt floor, rice husk as bed, covered with corrugated paper on the first week. The lighting program used was 24 hours per day (natural + artificial light) during the experimental period of 1 to 14 days of age.

Maximum and minimum temperatures were monitored throughout the experimental period; their values were recorded at $08 \mathrm{~h} 00$ and $16 \mathrm{~h} 00$, using a dry bulb thermometer. Average maximum and minimum temperatures were, respectively: $37.00 \pm 2.576$ and $26.00 \pm 2.386{ }^{\circ} \mathrm{C}$ in the morning and $38.00 \pm 5.409$ and $28.00 \pm 3.069{ }^{\circ} \mathrm{C}$ in the afternoon.

The diets consisted of six levels of threonine (10.80, $11.50,12.20,12.90,13.60$ and $14.30 \mathrm{~g} / \mathrm{kg}$ as fed), and all diets had the same amount of energy and nutrients, based on corn and soybean meal (Table 1). The chemical composition and energy values of feeds were based on Rostagno et al. (2005).

To meet the nutritional requirements of quails, we adopted the recommendations of Scherer (2009) for digestible lysine and metabolizable energy, and Silva (2008) for calcium and available phosphorus.

The dietary levels of digestible methionine+cystine and tryptophan were calculated according to ratio proposed by Rostagno et al. (2005) for broilers at the starter phase, from 1 to 21 days of age, corresponding to a digestible lysine:methionine+cystine ratio of 71 and digestible lysine: tryptophan ratio of 16 . All diets were supplemented with synthetic amino acids in sufficient amounts to reach the desired ratio for amino acids.

The animals were weighed weekly and the experimental diets were simultaneously weighed for estimation of body weight ( $g$ ), feed intake (g/bird), threonine intake (g/bird), weight gain $(\mathrm{g})$ and feed conversion $(\mathrm{g} / \mathrm{g})$.

Chemical composition of carcass was studied by comparative slaughter with an additional group of 50 quails at 1 day of age with average weigh $8.70 \pm 0.067 \mathrm{~g}$ and a group of five quails of 14 days of age selected by average weight $( \pm 10 \%)$ from each experimental unit ( 25 quails per treatment). Birds were slaughtered by decapitation between the occipital and atlas bones, with scissors, according to the rules established by the Ethics Committee on Animal Experiments of Universidade Estadual de Maringá - UEM.

One-day-old birds were dry-plucked while 14-day-old quails were bled and then boiled for 15 to 30 seconds at a temperature of $53-55{ }^{\circ} \mathrm{C}$ and plucked manually. After

Table 1 - Nutritional and centesimal composition of experimental diets for growing meat-type quails (as-fed basis)

\begin{tabular}{|c|c|c|c|c|c|c|}
\hline \multirow{2}{*}{ Ingredients } & \multicolumn{6}{|c|}{ Disgestible threonine levels ( $\mathrm{g} / \mathrm{kg}$ as fed) } \\
\hline & 10.8 & 11.5 & 12.2 & 12.9 & 13.6 & 14.3 \\
\hline Corn & 545.69 & 546.96 & 548.24 & 549.51 & 550.77 & 552.04 \\
\hline Soybean meal & 383.21 & 381.39 & 379.57 & 377.76 & 375.95 & 374.12 \\
\hline Soybean oil & 22.38 & 21.98 & 21.59 & 21.26 & 20.92 & 20.59 \\
\hline Dicalcium phosphate & 16.06 & 16.07 & 16.08 & 16.09 & 16.10 & 16.12 \\
\hline Limestone & 3.80 & 3.85 & 3.86 & 3.86 & 3.86 & 3.86 \\
\hline L-lysine HCL & 10.16 & 10.22 & 10.28 & 10.33 & 10.39 & 10.44 \\
\hline DL-methionine & 7.43 & 7.45 & 7.47 & 7.48 & 7.50 & 7.52 \\
\hline L-threonine & 3.65 & 4.45 & 5.27 & 6.06 & 6.85 & 7.64 \\
\hline L-tryptophan & 0.58 & 0.59 & 0.60 & 0.61 & 0.62 & 0.63 \\
\hline Salt & 3.94 & 3.94 & 3.94 & 3.94 & 3.94 & 3.94 \\
\hline Premix $^{1}$ & 3.00 & 3.00 & 3.00 & 3.00 & 3.00 & 3.00 \\
\hline Antioxidant $^{2}$ & 0.10 & 0.10 & 0.10 & 0.10 & 0.10 & 0.10 \\
\hline Total & 1000 & 1000 & 1000 & 1000 & 1000 & 1000 \\
\hline \multicolumn{7}{|c|}{ Calculated nutritional composition ( $\mathrm{g} / \mathrm{kg}$ as fed) } \\
\hline Crude protein & 235.00 & 235.00 & 235.00 & 235.00 & 235.00 & 235.00 \\
\hline Metabolizable energy (kcal/kg) & 2.997 & 2.997 & 2.997 & 2.997 & 2.997 & 2.997 \\
\hline Calcium & 6.50 & 6.50 & 6.50 & 6.50 & 6.50 & 6.50 \\
\hline Available phosphorus & 4.10 & 4.10 & 4.10 & 4.10 & 4.10 & 4.10 \\
\hline Digestible lysine & 18.80 & 18.80 & 18.80 & 18.80 & 18.80 & 18.80 \\
\hline Digestible methionine + cystine & 13.30 & 13.30 & 13.30 & 13.30 & 13.30 & 13.30 \\
\hline Digestible threonine & 10.80 & 11.50 & 12.20 & 12.90 & 13.60 & 14.30 \\
\hline Digestible tryptophan & 3.00 & 3.00 & 3.00 & 3.00 & 3.00 & 3.00 \\
\hline
\end{tabular}

${ }^{1}$ Vitamin/mineral supplementation (minimum levels per kg of premix); vit. A - 4,500,000 IU; vit. D3 - 1,250,000 IU; vit. E - 4,000 mg; vit. B1 - 278 mg; vit. B2 - 2,000 mg; vit. B6 - $525 \mathrm{mg}$; vit. B12 - 5,000 mcg; vit. K3 - 1,007 mg; calcium pantothenate - 4,000 mg; niacin - 10,000 mg; choline - 140,000 mg; antioxidant - 5,000 mg; zinc - 31,500 mg; iron - 24,500 mg; manganese - 38,750 mg; copper - 7,656 mg; cobalt - $100 \mathrm{mg}$; iodine - $484 \mathrm{mg}$; selenium - $127 \mathrm{mg}$.

${ }^{2}$ BHT (Butylated Hydroxytoluene). 
evisceration with an abdominal cut and removing the head and feet, the carcasses with skin were frozen in plastic bags properly identified for treatment/replication and then ground in an industrial meat grinder. Ground carcasses were weighed, homogenized and taken to a forced-ventilation oven at $55{ }^{\circ} \mathrm{C}$ for 72 hours for pre-drying. After pre-drying, they were ground in a ball mill and sent to the Animal Feed and Nutrition Laboratory for analytical determinations.

Dry matter, moisture, crude protein, ether extract and ash of carcass were determined according to Silva \& Queiroz (2004); protein (PDR) and fat (FDR) deposition rates and energy retained in the carcass (ERC) were calculated according to methodologies described by Fraga et al. (2008).

The protein deposition rate (PDR) in the carcass was calculated by comparative slaughter with an additional group of 50 one-day-old quails compared with those slaughtered at the end of the experimental period. The protein deposition rate in the carcass $(\mathrm{g})$ was calculated according to the equation:

$$
\mathrm{PDR}=\left(\mathrm{P}_{\mathrm{fc}}-\mathrm{P}_{\mathrm{ic}}\right) / \mathrm{PE}
$$

Where $P_{f c}$ is the final amount of protein in the carcass, in grams; $\mathrm{P}_{\text {ic }}$ is the initial amount of protein in the carcass and $\mathrm{PE}$ is the experimental period, in days. $\mathrm{P}_{\mathrm{fc}}$ was obtained by multiplying the carcass weight of a given individual at the end of the experiment by its carcass crude protein (CCP) content, while $\mathrm{P}_{\text {ic }}$ was obtained by the average weight of slaughtered and eviscerated birds at the beginning of the experiment, multiplied by its average crude protein content.

The fat deposition rate (FDR) on carcass was calculated according to the equation:

$$
\mathrm{FDR}=\left(\mathrm{F}_{\mathrm{fc}}-\mathrm{F}_{\mathrm{ic}}\right) / \mathrm{PE}
$$

Where $F_{f c}$ is the final amount of fat on the carcass, in grams; $F_{i c}$ is the initial amount of fat on the carcass; and $\mathrm{PE}$ is the experimental period, in days. $\mathrm{F}_{\mathrm{fc}}$ and $\mathrm{F}_{\mathrm{ic}}$ were obtained similarly to $\mathrm{F}_{\mathrm{fc}}$ and $\mathrm{F}_{\mathrm{c} \text {, }}$, using the values of carcass ether extract rather than the carcass crude protein.

The energy retained in the carcass (ERC) was calculated using the formula:

$$
\mathrm{ERC}=5.66 \mathrm{PDR}+9.37 \mathrm{FDR}
$$

Where 5.66 and 9.37 are the energy values (in $\mathrm{kcal} / \mathrm{g}$ ) of protein and fat, respectively, indicated by Sakomura (2004).

We performed an economic analysis of diets determining the cost of feed per kilogram of live weight gain $\left(\mathrm{Y}_{i}\right)$, according to Bellaver et al. (1985), by the formula:

$$
Y_{i}=\left(\mathrm{A}_{i} \times \mathrm{P}_{i}\right) / \mathrm{G}_{i}
$$

Where, $\mathrm{A} i$ is the amount of feed consumed; $\mathrm{P} i$ is the price per kilogram of feed used $(\mathrm{R} \$ / \mathrm{kg})$; and $\mathrm{G} i$ is the weight gain.
The statistical analysis was performed using the Sistema para Análises Estatísticas e Genéticas (SAEG, version 5.0), according to the model.

$$
\mathrm{Y}_{\mathrm{ij}}=\mathrm{b}_{0}+\mathrm{b}_{1} \mathrm{DThr}_{\mathrm{i}}+\mathrm{b}_{2} \mathrm{DThr}_{\mathrm{i}}^{2}+\mathrm{LA}+\mathrm{e}_{\mathrm{ij}}
$$

$\mathrm{Y} i j=$ measured variable in experimental unit $j$, fed a diet containing digestible threonine level $i$; $\mathrm{b}_{0}=$ overall constant; $b_{1}=$ linear regression coefficient according to the threonine level $; \mathrm{DThr}_{i}=$ digestible threonine level; $\mathrm{T} 1=$ $10.80, \mathrm{~T} 2=11.50, \mathrm{~T} 3=12.20, \mathrm{~T} 4=12.90, \mathrm{~T} 5=13.60$ and $\mathrm{T} 6=14.30 \mathrm{~g} / \mathrm{kg} ; \mathrm{b}_{2}=$ quadratic regression coefficient according to the threonine level; $L F=$ lack of fit on the regression model; $\mathrm{e}_{i l}=$ random error associated with each observation.

\section{Results and Discussion}

Dietary digestible threonine levels had a quadratic $(\mathrm{P}<0.05)$ effect on body weight (BW), feed intake (FI) and weight gain (WG) from 1-14 days (Table 2).

Estimates for maximum BW (79.41 g), FI (128.96 g/bird) and WG $(70.73 \mathrm{~g})$ were obtained with diets containing $12.60 \mathrm{~g} / \mathrm{kg}$ of digestible threonine, corresponding to a DThr:DL ratio of 67.02 (Figures 1 and 2).

Similar results of threonine:lysine ratio were described by Lima Neto et al. (2008), who also observed a quadratic effect on weight gain and final weight, estimating the requirements at 8.64 and $8.73 \mathrm{~g} / \mathrm{kg}$ of digestible threonine with a threonine:lysine ratio of 68 and 69 for broilers in the starter phase (1-7 days of age) fed diets containing different threonine levels.

In a study conducted with 1 to 20-day-old broilers fed different levels of dietary threonine $(6.84$ to $8.70 \mathrm{~g} / \mathrm{kg})$, Atêncio et al. (2004) observed a quadratic effect on weight gain and feed intake, whose best performances were obtained with $7.96 \mathrm{~g} / \mathrm{kg}$ of digestible threonine and threonine:lysine ratio of 68.6.

Evaluating threonine supplementation in diets for 1 to 21-day-old broilers, with different energy and energy:protein ratios, Reginnato et al. (2000) found no effect regardless of energy levels on the performance characteristics evaluated.

Threonine intake showed a quadratic effect $(\mathrm{P}<0.05)$ as the dietary threonine levels were increased (Table 2), but the estimate is above the levels studied. The model chosen was the regression equation which increased linearly $(\mathrm{P}<0.05)$ as the dietary threonine levels increased. However, with an adjustment of the data model considering the discontinuous LRP model, threonine intake presented an estimate of $1.75 \mathrm{~g} /$ bird $(\mathrm{P}<0.05)$ obtained with diets containing $13.40 \mathrm{~g} / \mathrm{kg}$ of threonine. Considering the estimate for FI and WG of 
Table 2 - Average performance values of meat-type quails from 1 to 14 days of age fed different digestible threonine (DThr) levels

\begin{tabular}{|c|c|c|c|c|c|c|c|c|c|c|}
\hline \multirow{2}{*}{ Variables } & \multicolumn{6}{|c|}{ Digestible threonine $(\mathrm{g} / \mathrm{kg})$} & \multirow{2}{*}{ CV $(\%)$} & \multicolumn{3}{|c|}{$\mathrm{P}$-value } \\
\hline & 10.80 & 11.50 & 12.20 & 12.90 & 13.60 & 14.30 & & Linear & Quadratic & Lack of fit \\
\hline Body weight at $14 \mathrm{~d}(\mathrm{~g})$ & 76.58 & 78.06 & 79.90 & 79.72 & 77.38 & 77.63 & 2.597 & 0.7211 & 0.0338 & 0.0952 \\
\hline Feed intake $(\mathrm{g} / \mathrm{bird})$ & 122.44 & 126.29 & 128.59 & 128.40 & 127.93 & 123.24 & 3.025 & 0.7316 & 0.0041 & 0.1246 \\
\hline Weight gain $(\mathrm{g})$ & 67.92 & 69.38 & 71.19 & 71.07 & 68.74 & 68.92 & 2.923 & 0.7316 & 0.0330 & 0.0987 \\
\hline Feed conversion $(\mathrm{g} / \mathrm{g})$ & 1.80 & 1.82 & 1.81 & 1.81 & 1.86 & 1.79 & 3.635 & 0.0001 & 0.7806 & 0.5935 \\
\hline \multicolumn{5}{|c|}{ Feed intake $=-184.457+49.5881 \mathrm{DTh} r-1.96138 \mathrm{DThr}^{1}$} & \multicolumn{2}{|c|}{0.97} & & \multicolumn{3}{|c|}{12.60} \\
\hline \multicolumn{5}{|c|}{ Threonine intake $=-0.0300571+0.128584 \mathrm{DThr}$} & \multicolumn{2}{|c|}{0.96} & & \multicolumn{3}{|c|}{-----} \\
\hline \multicolumn{5}{|c|}{ Threonine intake $=-0.3945+1.5987 \mathrm{DThr}$} & \multicolumn{2}{|c|}{0.90} & & \multicolumn{3}{|c|}{13.40} \\
\hline \multicolumn{5}{|c|}{ Weight gain $=-62.3447+21.0859 \mathrm{DThr}-0.835250 \mathrm{DTh}^{1}$} & \multicolumn{2}{|c|}{0.73} & & \multicolumn{3}{|c|}{12.60} \\
\hline
\end{tabular}

${ }^{1}$ Threonine intake $=$ feed intake $\times$ digestible threonine level/100.

$\mathrm{CV}$ - coefficient of variation.
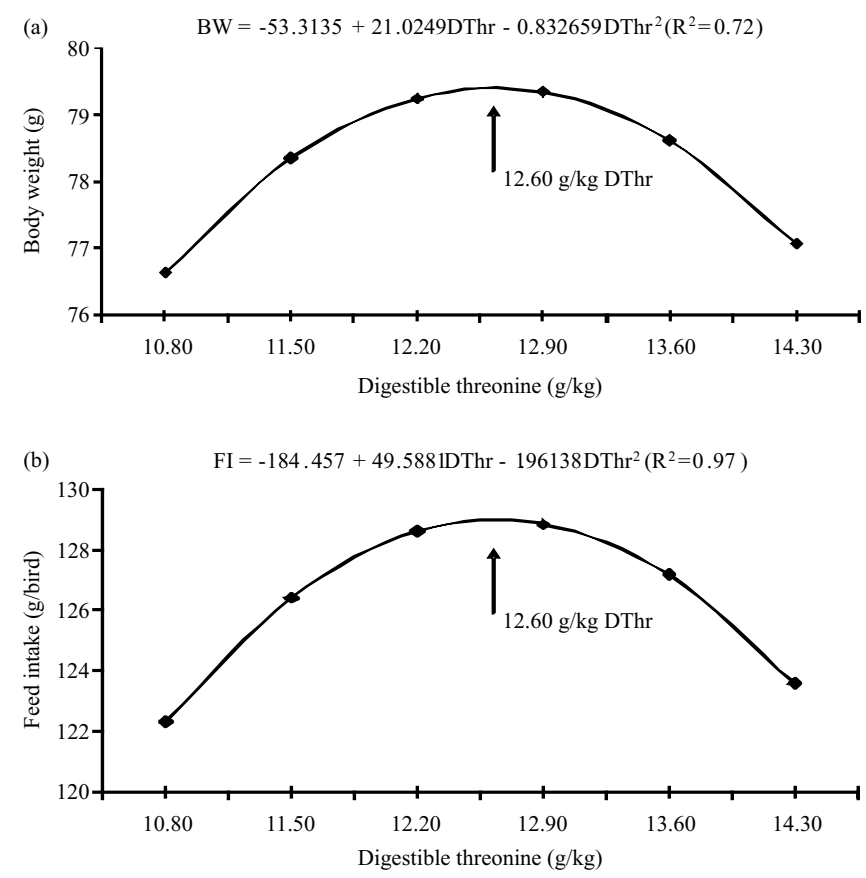

Figure 1 - Body weight (BW) and feed intake (FI) of meat-type quails at 14 days of age (a) from 1 to 14 days of age (b) fed different digestible threonine (DThr) levels

$12.60 \mathrm{~g} / \mathrm{kg}$ of threonine, we can safely affirm that there was a lower intake of threonine $(1.62 \mathrm{~g} / \mathrm{bird})$ and other amino acids, preventing better performance (Figure 3 ).

A high intake of threonine can generate an unnecessary increase of body heat, causing an excessive excretion of uric acid with increased energy expenditure and consequently, increased production costs (Goulart, 1997). The metabolic cost to incorporate an amino acid into the protein chain is estimated at $4 \mathrm{~mol}$ of ATP, and the cost to excrete one amino acid is estimated at about 6-18 moles of ATP, depending on the amount of nitrogen present in the amino acid. Thus, the degradation of excess amino acid in the diet has a high energy cost for birds (Pereira et al., 2009).

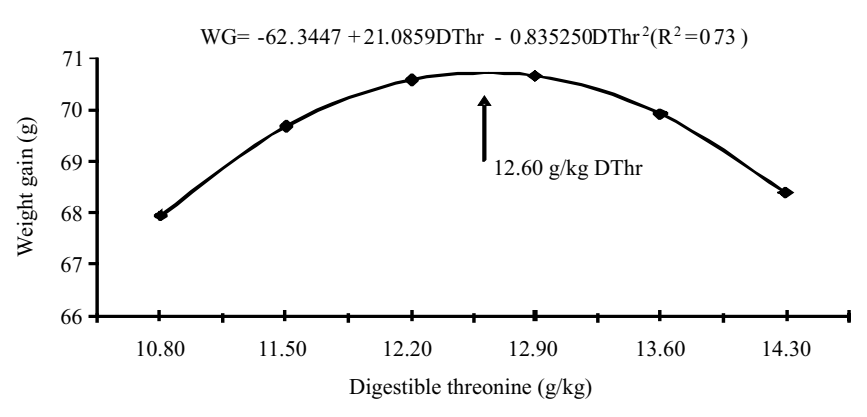

Figure 2 - Weight gain (WG) of meat-type quails from 1 to 14 days of age fed different digestible threonine (DThr) levels

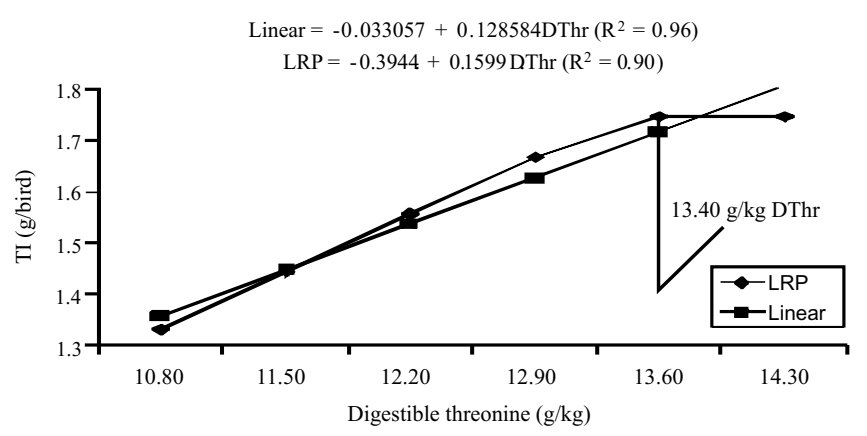

LRP - Linear Response Plateau.

Figure 3 - Threonine intake (TI) of meat-type quails from 1 to 14 days of age fed different digestible threonine (DThr) levels.

Umigi et al. (2012), assessing the nutrient requirement of threonine for Japanese quails in egg production, found no effect of threonine levels (5.50 to $7.50 \mathrm{~g} / \mathrm{kg}$ ) on performance variables, except for threonine intake, which increased linearly. According to the authors, the variation observed in threonine intake, due to the increased diet concentration of threonine can be justified by the fact that the feed intake did not vary between treatments. Therefore, the lowest level 
of threonine $(5.50 \mathrm{~g} / \mathrm{kg})$ was sufficient to meet the quail requirements without compromising performance.

According to Silva \& Ribeiro (2001), in the starter phase (1-21 days) quails increase seven times their initial weight, due to muscle hypertrophy, especially the pectoral muscles, bones and internal organs. The accelerated growth rate of quails reported by these authors was lower than the values of this trial, where quails had an initial average weight of $8.68 \mathrm{~g}$ reaching the maximum estimated body weight of $79.41 \mathrm{~g}$, with diets containing $12.60 \mathrm{~g} / \mathrm{kg}$ of digestible threonine, increasing their initial weight by nine times.

According to González \& Sartori (2002), the protein synthesis rate is higher in young animals, during growth. The accelerated growth found in this study may be related to the role of threonine, which is required for protein synthesis and maintenance of body protein turnover.

The accelerated growth rate shows the importance of adequate intake of amino acids for muscle protein deposition, protein synthesis and maintenance of body protein turnover in addition to the calcium and phosphorous necessary for bone tissue formation during the starter phase. Thus, the intake of these nutrients below the requirements may compromise growth in birds.

Feed conversion was not affected $(\mathrm{P}>0.05)$ by threonine levels from 1 to 14 days of age. These results contradict those obtained by Costa et al. (2009), who observed a quadratic effect on feed intake and feed conversion for 1 to 21-day-old laying quails, whose best estimate for feed conversion came from diets containing $11.00 \mathrm{~g} / \mathrm{kg}$ of digestible threonine.

Baylan et al. (2006), evaluating the performance of 1 to 14-day-old Japanese quails fed different levels of total threonine, found no effect of total threonine on feed conversion, which is consistent with the present work.

According to Silva et al. (2007), there are similarities and differences between the nutritional specifications for quails strains, both for growth and egg laying. Although the recommendation for protein and energy levels are very similar, the levels of calcium, available phosphorus and amino acid profile are higher for meat-type quails, which can be explained by higher weigh gain and muscle growth of these birds, especially in the first four weeks of age.

The chemical components of the carcass - water, crude protein, fat, ash and fat deposition rate (FDR) - in the carcass meat were not affected $(\mathrm{P}>0.05)$ by the threonine levels studied here (Table 3). These results corroborate those obtained by Reginatto et al. (2000), who observed no effect on carcass composition of broilers with different levels of digestible threonine in the diet.

Protein deposition rate (PDR) and energy retained in the carcass $(\mathrm{ERC})$ showed a quadratic effect $(\mathrm{P}<0.05)$ as a function of threonine levels in the diet (Figure 4). The estimates for maximum PDR $(2.00 \mathrm{~g} / \mathrm{d})$ and ERC $(15.88 \mathrm{kcal} / \mathrm{g})$ were obtained with diets containing 11.80 and $12.00 \mathrm{~g} / \mathrm{kg}$ of digestible threonine, respectively, corresponding to DThr:DL ratios of 62.77 and 63.83 .

Considering that ERC is a variable dependent on PDR and FDR as well as on the energy values of protein and fat (5.66 and 9.37), it was expected that the effect would follow the behavior of one or two other related variables in agreement with the results founded in this trial; however, the coefficients of variation of the abovementioned variables are $10 \%$, indicating strong dispersion of data.

According to Mack \& Pack (2000), an adequate intake of protein with unbalanced amino acid profile will direct

Table 3 - Carcass chemical composition, protein deposition rate, fat deposition rate and energy retained in the carcass in meat-type quails from 1 to 14 days fed different digestible threonine (DThr) levels

\begin{tabular}{|c|c|c|c|c|c|c|c|c|c|c|}
\hline \multirow{2}{*}{ Variables } & \multicolumn{6}{|c|}{ Digestible threonine $(\mathrm{g} / \mathrm{kg})$} & \multirow{2}{*}{$\mathrm{CV}(\%)$} & \multicolumn{3}{|c|}{ P-value } \\
\hline & 10.80 & 11.50 & 12.20 & 12.90 & 13.60 & 14.30 & & Linear & Quadratic & Lack of fit \\
\hline \multicolumn{11}{|c|}{ Carcass chemical composition (g/kg) } \\
\hline Water & 735.40 & 727.50 & 734.90 & 728.20 & 727.50 & 732.60 & 0.725 & 0.4085 & 0.3450 & 0.1333 \\
\hline Protein & 732.50 & 717.30 & 720.10 & 729.90 & 684.10 & 722.50 & 2.394 & 0.1372 & 0.2594 & 0.0111 \\
\hline Fat & 167.80 & 182.90 & 166.60 & 179.10 & 212.50 & 165.00 & 11.064 & 0.4021 & 0.4256 & 0.0275 \\
\hline Ash & 123.70 & 117.50 & 121.50 & 126.40 & 112.50 & 117.10 & 8.352 & 0.3122 & 0.5686 & 0.4340 \\
\hline \multicolumn{11}{|c|}{ Deposition rate (g/day) } \\
\hline Protein & 1.86 & 2.19 & 1.75 & 2.06 & 1.65 & 1.51 & 13.278 & 0.0204 & 0.0172 & 0.0092 \\
\hline Fat & 0.40 & 0.54 & 0.38 & 0.48 & 0.53 & 0.32 & 25.758 & 0.5188 & 0.2397 & 0.0692 \\
\hline $\mathrm{ERC}(\mathrm{kcal} / \mathrm{g})$ & 14.27 & 17.49 & 13.47 & 16.18 & 14.31 & 11.53 & 15.903 & 0.0821 & 0.0484 & 0.0288 \\
\hline Regression equ & & & & \multicolumn{4}{|c|}{$\mathrm{R}^{2}$} & \multicolumn{3}{|c|}{ Estimate $(\mathrm{g} / \mathrm{kg})$} \\
\hline \multirow{2}{*}{\multicolumn{5}{|c|}{$\begin{array}{l}\mathrm{PDR}=-9.25268+1.90905 \mathrm{DThr}-0.0809714 \mathrm{DThr}^{2} \\
\mathrm{ERC}=-96.8759+18.7710 \mathrm{DThr}-0.781216 \mathrm{DThr}^{2}\end{array}$}} & \multicolumn{2}{|c|}{0.59} & & \multicolumn{3}{|c|}{11.80} \\
\hline & & & & & \multicolumn{2}{|c|}{0.53} & & \multicolumn{3}{|c|}{12.00} \\
\hline
\end{tabular}

$\mathrm{CV}$ - coefficient of variation; ERC - energy retained in the carcass; PDR - protein deposition rate. 
Table 4 - Price of experimental diets and cost per kilogram of live weight gained in meat-type quails fed different digestible threonine (DThr) levels

\begin{tabular}{|c|c|c|c|c|c|c|c|c|c|c|}
\hline \multirow{2}{*}{ Variables } & \multicolumn{6}{|c|}{ Digestible threonine $(\mathrm{g} / \mathrm{kg})$} & \multirow{2}{*}{ CV $(\%)$} & \multicolumn{3}{|c|}{ P-value } \\
\hline & 10.80 & 11.50 & 12.20 & 12.90 & 13.60 & 14.30 & & Linear & Quadratic & Lack of fit \\
\hline \multicolumn{11}{|c|}{ Carcass chemical composition $(\mathrm{g} / \mathrm{kg})$} \\
\hline Diet price $(\mathrm{R} \$ \mathrm{~kg})$ & 0.81 & 0.82 & 0.83 & 0.84 & 0.85 & 0.87 & ------ & ------ & ----- & ----- \\
\hline Cost (R \$/kg LW gained) & 1.45 & 1.49 & 1.50 & 1.52 & 1.59 & 1.55 & 3.630 & 0.0005 & 0.0022 & 0.0249 \\
\hline Regression equation & \multicolumn{10}{|c|}{$\mathrm{R}^{2}$} \\
\hline Cost $=1.10371+0.32844$ & \multicolumn{10}{|c|}{0.80} \\
\hline
\end{tabular}

$\mathrm{CV}$ - coefficient of variation.

(a) $\quad \mathrm{PDR}=-9.25268+1.90905 \mathrm{DThr}-0.0809714 \mathrm{DThr}^{2}\left(\mathrm{R}^{2}=0.59\right)$
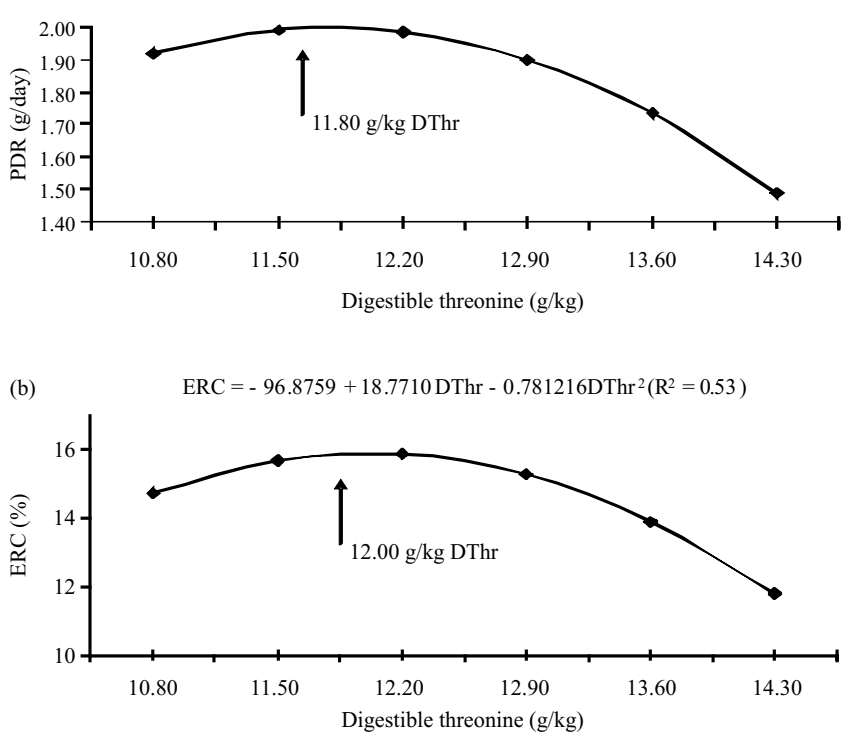

Figure 4 - Protein deposition rate (PDR; a) and energy retained in the carcass (ERC; b) of meat-type quails at 14 days of age fed different digestible threonine (DThr) levels.

the diet energy to fat deposition rather than for body protein synthesis. As a consequence, fat deposition rate increases and a protein deposition is reduced. The amino acid profile used in this study allowed for the efficient use to promote a higher protein deposition without compromising fat deposition.

The cost of feed per kilogram of live weight gained (Table 4$)$ increased linearly $(\mathrm{P}<0.05)$ according to digestible threonine levels in the diet. According to the regression equation $($ Cost $=1.10371+0.328449 \mathrm{DThr})$, for every $1 \%$ threonine added to diet, there was an increase in feed cost of $0.33 \mathrm{R} \$ / \mathrm{kg}$ of live weight gained. The high amino acid content of the experimental diets was only achieved with inclusion of synthetic amino acids, increasing the feed cost.

\section{Conclusions}

The nutrient requirement of digestible threonine for meat-type quails from 1 to 14 days of age is $12.60 \mathrm{~g} / \mathrm{kg}$, corresponding to a digestible threonine:digestible lysine ratio of 67.02 .

\section{References}

ATÊNCIO, A.; ALBINO, L.F.T.; ROSTAGNO, H.S. et al. Exigências de treonina para frangos de corte machos nas fases de 1 a 20,24 a 38 e 44 a 56 dias de idade. Revista Brasileira de Zootecnia, v.33, n.4, p.880-893, 2004.

BAYLAN, M.; CANOGULlARI, S.; AYASAN, T. et al. Dietary threonine supplementation for improving growth performance and edible carcass parts in Japanese quails, Coturnix coturnix japonica. Journal of Poultry Science, v.5, n.7, p.635-638, 2006.

BELLAVER, C.; FIALHO, E.T.; PROTAS, J.F.S. et al. Radícula de malte na alimentação de suínos em crescimento e terminação. Pesquisa Agropecuária Brasileira, v.20, n.8, p.969-74, 1985.

BRUMANO, G. Níveis de lisina e de metionina + cistina e proteína bruta para melhor qualidade de ovo e de carcaça de aves e de suínos. Revista Eletrônica Nutritime, v.6, n.3, p.898-917, 2009.

COSTA, F.G.P.; NOBRE, I.S.; SILVA, L.P.G. et al. Exigência de treonina digestível para codornas japonesas na fase inicial. In: REUNIÃO ANUAL DA SOCIEDADE BRASILEIRA DE ZOOTECNIA, 46., 2009, Maringá. Anais... Maringá: Sociedade Brasileira de Zootecnia, 2009. (CD-ROM).

FRAGA, A.L.; MOREIRA, I.; FURLAN, A.C. et al. Lysine requirement of starting barrows from two genetic groups fed on low crude protein diets. Brazilian Archives of Biology and Technology, v.51, n.1, p.49-56, 2008.

GONZÁLES, E.; SARTORI, J.R. Crescimento e metabolismo muscular. In: MACARI, M.; FURLAN, R.L.; GONZÁLES, E. (Eds.) Fisiologia aviária aplicada a frangos de corte. 2.ed. Jaboticabal: FUNEP/UNESP, 2002. 375p.

GOULART, C.C. Exigência nutricional de lisina para poedeiras leves e semipesadas. 1997. 51f. Dissertação (Mestrado em Nutrição de Monogástrico) - Universidade Federal de Viçosa, Viçosa, MG.

LELIS, G.R.; CALDERANO, A.A. proteína ideal para poedeiras semipesadas. Revista Eletrônica Nutritime, v.8, n.2, p.1482-1488, 2011.

LIMA NETO, R.C.; COSTA, F.G.P.; GOULART, C.C. et al. Exigência de treonina digestível glicina + serina e relações de treonina: lisina e glicina + serina:lisina para pintos de corte machos na fase inicial. In: REUNIÃO ANUAL DA SOCIEDADE BRASILEIRA DE ZOOTECNIA, 45., 2008, Lavras. Anais... Lavras: SBZ, 2008. (CD-ROM). 
MACK, S.; PACK, M. Desenvolvimento de carcaça de frango: influência dos aminoácidos da dieta. In: CONFERÊNCIAAPINCO DE CIÊNCIA E TECNOLOGIA AVÍCOLA, 2000, Campinas. Anais... Campinas, 2000. p.145-160.

MÓRI, C.; GARCIA, E.A.; PAVAN, A.C. et al. Desempenho e rendimento de carcaça de quatro grupos genéticos de codornas para produção de carne. Revista Brasileira de Zootecnia, v.34, n.3, p.870-876, 2005.

PEREIRA. A.A.; JUNQUEIRA, O.; PRAES, M.F.F.M. [2009] Avicultura e meio ambiente. Available at: $<$ http://www.aveworld.com.br/artigos/ post/avicultura-e-meio-ambiente 7056.> Accessed on: Mar. 20, 2010.

REGINATTO, M.F.; RIBEIRO, A.M.L.; PENZ JUNIOR, A.M. et al. Suplementação de treonina em dietas de frangos de corte, variando a energia e as relações energia:proteína. Revista Brasileira de Ciência Avícola, v.2, n.3, p.239-247, 2000.

ROSTAGNO, H.S.; ALBINO, L.F.T.; DONZELE, J.L. et al. Tabelas brasileiras para aves e suínos: composição de alimentos e exigências nutricionais. 2.ed. Viçosa, MG: UFV, Departamento de Zootecnia, 2005. 186p.

SAKOMURA, N.K. Modeling energy utilization in broiler breeders, laying hens and broilers. Revista Brasileira de Ciência Avícola, v.6, n.1, p.1-11, 2004.

SCHERER, C. Exigência nutricional de energia metabolizável, lisina digestível e metionina+cistina digestível para codornas de corte em fase de crescimento. 2009. 118f. Tese (Doutorado em Zootecnia) - Universidade Estadual de Maringá, Maringá
SILVA, D.J.; QUEIROZ, A.C.D. Análises de alimentos. 3.ed. Viçosa, MG: UFV, 2004. 235p.

SILVA, J.H.V.; RIBEIRO, M.L.G. Tabela nacional de exigência nutricional de codornas (Coturnix coturnix japonica). Bananeiras: DAP/UFPB/Campus IV, 2001. 19p.

SILVA, J.H.V.; COSTA, F.G.P.; SILVA, E.L. et al. Exigências nutricionais de codornas. In: SIMPÓSIO INTERNACIONAL, 3., CONGRESSO BRASILEIRO DE COTURNICULTURA, 2., Lavras. Anais... Lavras/NECTA, 2007. p.44-64.

SILVA, R.M. Exigência nutricional de cálcio e de fósforo de codornas de corte (Coturnix coturnix sp) em crescimento. 2008. 48f. Dissertação (Mestrado em Zootecnia) - Universidade Estadual de Maringá, Maringá.

UMIGI, R.T.; BARRETO, S.L.T.; DONZELE, J.L. et al. Níveis de treonina digestível em dietas para codornas japonesa em postura. Revista Brasileira de Zootecnia, v.36, n.6, p.1868-1874, 2007.

UMIGI, R.T.; BARRETO, S.L.T.; REIS, R.S. et al. Níveis de treonina digestível para codornas japonesa na fase de postura. Arquivo Brasileiro de Medicina Veterinária e Zootecnia, v.64, n.3, p.658-664, 2012.

WINTER, E.M.W.; ALMEIDA, M.I.M.; OLIVEIRA, E.G. et al. Aplicação do método Bayesiano na estimação de correlações genéticas e fenotípicas de peso em codornas de corte em várias idades. Revista Brasileira de Zootecnia, v.35, n.4, p.1684-1690, 2006 (supl.) 